\title{
Correction to: Think ahead before you regulate: A focus on future consequences predicts choices of and beliefs about strategies for the downregulation of negative emotions
}

\author{
Catherine N. M. Ortner ${ }^{1}\left[\right.$ ] Leah Chadwick ${ }^{1}$. Alexis M. Wilson ${ }^{1}$
}

Published online: 1 August 2018

(c) Springer Science+Business Media, LLC, part of Springer Nature 2018

\section{Correction to: Motivation and Emotion \\ https://doi.org/10.1007/s11031-018-9705-3}

The original version of this article unfortunately contained a mistake in the last paragraph of result section in Study 1. It should read as "Future focus was positively associated with reappraisal, $\mathrm{r}=.21, \mathrm{p}=.005$, and situation modification, $\mathrm{r}=.261, \mathrm{p}<.001$, and negatively associated with acting out, $\mathrm{r}=.18, \mathrm{p}=.02$, and learned helplessness, $\mathrm{r}=.21, \mathrm{p}=.004$ ". 